\title{
ARTYKUtY
}

Klio. Czasopismo poświęcone dziejom Polski i powszechnym

PL ISSN 1643-8191, t. 33 (2)/2015, s. 73-101

(c) $(1)$

http://dx.doi.org/10.12775/KLIO.2015.019

\author{
ADAM KUCHARSKI ${ }^{*}$
}

\section{Grand Tour Tomasza, Michała i Marcina Zamoyskich z przełomu XVII i XVIII wieku}

\section{Tomasz, Michal, and Marcin Zamoyski's Grand Tour from the turn of the $17^{\text {th }}$ and $18^{\text {th }}$ century}

Streszczenie: Podróże typu Grand Tour zyskały dużą popularność w drugiej połowie XVII wieku. Jako pierwszy użył tego terminu angielski autor Richard Lassels. Nazwał w ten sposób wyjazdy szlachty do Francji, Włoch, Holandii i Niemiec. Podróże tego rodzaju łączyły aspekty edukacyjne i poznawcze. Peregrynanci, wywodzący się przede wszystkim ze szlachty i arystokracji europejskiej, odbywali studia prywatne lub uniwersyteckie, a także zwiedzali w trakcie podróży wiele miast, gdzie podziwiali dzieła sztuki i architektury. Ten typ podróżowania narodził się w Europie Zachodniej, a w szczególności w Anglii. Także w Rzeczypospolitej szlacheckiej zdobył sobie szybko duże uznanie wśród polskiej szlachty i magnaterii. Głównym celem, który autor tego artykułu sobie postawił, jest rekonstrukcja przebiegu podróży trzech braci, synów wojewody lubelskiego i podskarbiego wielkiego koronnego Marcina Zamoyskiego i Anny z Gnińskich na przełomie XVII i XVIII wieku. Po śmierci ich ojca wychowaniem synów zajęła się matka. Tomasz Józef oraz jego młodsi

* Instytut Historii i Archiwistyki Uniwersytetu Mikołaja Kopernika w Toruniu, ul. W. Bojarskiego 1, 87-100 Toruń, e-mail: akr88@umk.pl. 
bracia Michał Zdzisław i Marcin Leopold Zamoyscy wyruszyli w 1697 roku w czteroletnią podróż. Ich celem był pobyt w kilku europejskich krajach. Podróżowali po terenach Śląska, Czech, Austrii, Niemiec, Francji, Anglii, Holandii i Włoch. Studiowali w Pradze, Paryżu, Ingolstadt oraz zwiedzali Wiedeń, Augsburg, Stuttgart, Strasburg, Brukselę, Hagę, Amsterdam, Paryż, Rzym, Londyn, Neapol i wiele innych miast. Do Polski wrócili w końcu 1701 roku.

Abstract: In the second half of the $17^{\text {th }}$ century travels of the Grand Tour type became very popular. Englishman Richard Lassels, as first, used designation the Great Travel (French Grand Tour). He named in this way journeys of countrymen to France, Italy, Netherlands and Germany. Trips of this kind combined educational aspects and cognitive advantages. Travelers was descended mainly from gentry and aristocracy, studied privately or at universities and went sightseeing many cities, and admired works of art and architecture. This type of traveling arose in Western Europe, particularly in England. Also in Poland journeys called Grand Tour won the recognition very quickly. Many representatives of Polish nobles and aristocracy sent their sons into abroad travels. The main purpose of this article is to describe a course of travel of three brothers, sons of Marcin Zamoyski, province governor of Lublin and treasurer of crown, and Anna Gnińska, in the end of $17^{\text {th }}$ century and in the beginning of $18^{\text {th }}$ century. After the death of father, the mother took care for upbringing of sons. Tomasz Józef, and younger brothers, Michał Zdzisław and Marcin Leopold Zamoyski set off in the year 1697 on the four-year journey. They traveled to Silesia, Czech, Austria, Germany, France, England, Netherlands and Italy. They studied in Prague, Paris and Ingolstadt, and visited Vienna, Augsburg, Stuttgart, Strasbourg, Brussels, Amsterdam, Hague, Paris, Rome, London, Naples and many other cities. They came back to Poland in the end of 1701 .

Słowa kluczowe: Grand Tour, podróże, Tomasz Zamoyski, Marcin Zamoyski, Michał Zamoyski

Keywords: Grand Tour, travels, Thomas Zamoyski, Martin Zamoyski, Michael Zamoyski

ednym z czołowych przejawów mobilności społecznej, uwarunkowanej
kulturowo i edukacyjnie, europejskiej elity szlachecko-magnackiej sta-
fy się w XVII i XVIII wieku podróże typu Grand Tour (Kavalierstour) ${ }^{1}$.

${ }^{1} \mathrm{Z}$ bogatej literatury przedmiotu zob. m.in.: J. Buzard, The Grand Tour and after (1660-1840), [w:] The Cambridge Companion to Travel Writing, ed. P. Hulme and T. Youngs, Cambridge 2002, s. 37-52; M. Bratuń, O sztuce podróżowania $w$ dawnej Europie, „Strony” 1997, nr 5-6(17-18), s. 59-62; N. Conrads, Politische und staatsrechtliche Probleme der Kavalierstour, [w:] Reiseberichte als Quellen europäischer Kulturgeschichte, 
Wyjazdy tego rodzaju, których nazwę wprowadził w drugiej połowie XVII wieku Richard Lassels na określenie poznawczo-edukacyjnych wojaży Anglików po centrach europejskiej kultury, nauki i sztuki, były niezbędnym elementem formacji intelektualnej szlachty europejskiej². Podróże tego typu, uznane przez Antoniego Mączaka za synonim „wielkiego objeżdżania Europy”, łączyły w sobie studia i zwiedzanie najatrakcyjniejszych kulturowo i artystycznie regionów kontynentu z Francją i Włochami na czele $^{3}$. W zasadzie od samego początku funkcjonowania Grand Tour można także mówić o znacznej popularności takich wojaży wśród Polaków4 W ostatnim czasie charakterystyce tego zjawiska na gruncie polskim poświęcono odrębne studium ${ }^{5}$.

W życiu i karierze młodych przedstawicieli rodu Zamoyskich już od XVI wieku istotną rolę odgrywały podróże zagraniczne, w które wyjeżdżano dla odbycia studiów na znanych europejskich uniwersytetach i akademiach. Były one wyrazem wysokiej rangi społecznej i wykładnią mobilnego trybu życia polskiej magnaterii, spędzającej sporą część życia w podróżach krajowych i zagranicznych ${ }^{6}$. W statucie ordynacji zamojskiej zagraniczne wyjazdy naukowo-poznawcze odgrywały ważną rolę. Na ich realizację rezerwowano specjalne środki finansowe. Magnaci koronni z rodu Zamoyskich wysyłali swoich synów nie tylko po naukę humaniorów, edukacji rycerskiej czy poznanie świata. Nie mniej ważnym celem było zdobycie wiedzy

hrsg. von A. Mączak, H. J. Teuteberg, Wolfenbüttel 1982, s. 45-64; J. Black, The British Abroad. The Grand Tour in the Eighteenth Century, London 2003.

${ }^{2}$ M. Bratuń, Z dziejów europejskiego „Grand Tour” w XVII i XVIII wieku, „Kwartalnik Opolski” 2003, t. 1, s. 7-9.

${ }^{3}$ A. Mączak, Turystyka europejska. Wieki XVI-XIX, „Folia Turistica” 2008, nr 19, s. $8-9$.

${ }^{4}$ Zob. A. Markiewicz, Grand Tour Aleksandra Jana i Jana Stanistawa Jabtonowskich z lat osiemdziesiatych XVII w., „Zeszyty Naukowe Uniwersytetu Jagiellońskiego” 2005, Prace Historyczne, z. 132, s. 57-69. 2014.

${ }^{5}$ Polski Grand Tour w XVIII i początkach XIX wieku, red. A. Roćko, Warszawa

${ }^{6}$ W. Czapliński, J. Długosz, Życie codzienne magnaterii polskiej w XVII w., Warszawa 1982, s. 99-104. 
praktycznej, mogącej przynieść wymierne efekty w procesie modernizacji gospodarki ordynackiej i zarządu majątkami .

W latach 1697-1701 po kilku krajach europejskich podróżowali bracia Tomasz Józef, Michał Zdzisław oraz Marcin Leopold Zamoyscy, synowie IV ordynata zamojskiego, wojewody lubelskiego i podskarbiego wielkiego koronnego Marcina Zamoyskiego (1637-1689) oraz jego żony Anny Franciszki z Gnińskich ${ }^{8}$. W dotychczasowej literaturze naukowej materiały dotyczące tej peregrynacji były już wykorzystywane. Działo się to jednak głównie w odniesieniu do dziejów polskich podróży, a nie samego rodu Zamoyskich ${ }^{9}$. Dotychczas głębszej analizie poddano jedynie krótkie fragmenty tej peregrynacji. Pobyt w Czechach został opracowany na podstawie jednego z diariuszy ${ }^{10}$. Natomiast francuską część podróży przybliżono w monografii i artykułach poświęconych edukacyjnym wyjazdom polskim do tego kraju ${ }^{11}$. Szczegółowego omówienia wymagają jeszcze trzy ważne etapy wyprawy (niemiecki, niderlandzko-angielski i włoski), których przebieg obszernie scharakteryzowali podróżnicy w swoich relacjach epistolograficznych. Brak całościowego przedstawienia przebiegu i charakteru tej podróży typu Grand Tour skłonił autora do podjęcia próby nakreślenia jej specyfiki w oparciu o materiały źródłowe.

W XVI i XVII wieku zagraniczne wyjazdy studyjno-poznawcze były ważnym punktem edukacji kolejnych ordynatów: kanclerza koronnego

${ }^{7}$ R. Orłowski, Ordynacja zamojska, [w:] Zamość i Zamojszczyzna w dziejach i kulturze polskiej, red. K. Myśliński, Zamość 1969, s. 109.

${ }^{8}$ M. Kozaczka, Poczet ordynatów Zamoyskich, Lublin 2004, s. 43-56.

9 Zob. Zamoyscy, Zamość i Ordynacja Zamojska w badaniach końca XIX i XX w., red. R. Szczygieł, Zamość 2005.

${ }^{10}$ H. Gmiterek, Czechy w diariuszu podróży Michata Zdzistawa Zamoyskiego z końca XVII wieku, [w:] Rola komunikacji i przestrzeni w średniowiecznych i wczesnonowożytnych dziejach Czech i Polski, red. A. Paner i W. Iwańczak, Gdańsk 2008, s. 292-305.

${ }_{11}$ M. Kamecka, „Do cudzych krajów”. Edukacyjne podróże szlachty polskiej do Francji w epoce saskiej, Białystok 2012; eadem, „Po naukę świata i ludzi.” O zagranicznej edukacji Polaków czasów saskich, [w:] Między barokiem a oświeceniem. Edukacja wyksztatcenie wie$d z a$, red. S. Achremczyk, Olsztyn 2005, s. 40-42; eadem, Francja i Francuzi w oczach podróżników polskich z przetomu XVII i XVIII w., [w:] Anglosasi, Francuzi i Polacy-wzajemny wizerunek dawniej i dzis, red. P. Guzowski i M. Kamecka, Białystok 2005, s. 73-86. 
Jana, Tomasza i Jana „Sobiepana” Zamoyskich" ${ }^{12}$. W tę tradycję wyjazdów edukacyjnych włącza się również peregrynacja akademicka synów IV ordynata Marcina Zamoyskiego. Po jego śmierci zarządzaniem dobrami ordynacji zamojskiej oraz wychowaniem pięciorga dzieci (najstarszy syn Jan Franciszek zmarł w 1690 roku) zajęła się Anna Zamoyska, korzystając z pomocy opiekunów prawnych ${ }^{13}$. Jednak współpraca z nimi nie układała się najlepiej, a dodatkowo osamotniona Anna Zamoyska musiała odpierać ataki licznych adwersarzy ${ }^{14}$. W takiej atmosferze odbywały się przygotowania do wysłania synów na studia zagraniczne.

Najstarszy z braci Tomasz Józef (1679-1725) piastował godność $\mathrm{V}$ ordynata zamojskiego, a także urzędy starosty płoskirowskiego i grodeckiego. Był żonaty z Teresą Potocką, a następnie z Antoniną Zahorowską ${ }^{15}$. Michał Zdzisław (1680-1735) został po śmierci brata VI ordynatem zamojskim. Pełnił też urzędy wojewody smoleńskiego, starosty bolimowskiego i gniewskiego oraz łowczego wielkiego koronnego. Był dwukrotnie żonaty: z Anną Działyńską i Elżbietą Wiśniowiecką ${ }^{16}$. Najmłodszy z braci i najwcześniej zmarły, starosta bolimowski Marcin Leopold (1681-1718) ożenił się z księżniczką Konstancją Drucką-Podbereską ${ }^{17}$. Michał Zdzisław osiągnął wysokie godności wchodząc do senatu ${ }^{18}$. Odnowił dobra ordynacji rodowej i dbał o rozwój Akademii Zamojskiej, strzegąc przede wszystkim

12 A. A. Witusik, O Zamoyskich, Zamościu i akademii zamojskiej, Lublin 1978, s. 19; Archiwum nacji polskiej w uniwersytecie padewskim, t. 1, opr. H. Barycz, Wrocław 1971, s. 56, 427; S. Żurkowski, Żyot Tomasza Zamojskiego kanclerza wielkiego koronnego, wyd. A. Batowski, Lwów 1860; J. Heidenstein, Peregrynacja Jana Heidensteina przez Belgię, Francję $i$ Wtochy w roku 1631 zaczęta a w roku 1634 zakończona, opr. Z. Pietrzyk, tłum. A. Golik-Prus, Kraków 2005, s. 102.

${ }^{13}$ Ludzie i zdarzenia $w$ barokowym Zamościu, opr. H. Wiśniewska, Lublin 1996, s. 147.

${ }^{14}$ R. Orłowski, op. cit., s. 111-112; L. Glatman, Sukcesorów Imci Pana Ordynata Marcina Zamoyskiego spór o ordynację (przyczynek do dziejów ordynacji zamojskiej z czasów saskich), Zamość 1921.

${ }^{15}$ M. Kozaczka, op. cit., s. 43-49.

${ }^{16}$ Ibidem, s. 51-56.

17 T. Zielińska, Poczet polskich rodów arystokratycznych, Warszawa 1997, s. 470.

${ }_{18}$ Eadem, Magnateria polska epoki saskiej, Wrocław-Warszawa-Kraków-Gdańsk 1977, s. 176-177. 
jej przywilejów. Troska tego ordynata dotyczyła głównie ochrony i sprawnego funkcjonowania akademii, lecz nie objęła w ogóle reformy studiów, ugruntowując znaczenie szkoły zamojskiej jako ostoi konserwatyzmu ${ }^{19}$. Świadomy własnego znaczenia i pozycji, dbał o uwiecznienie swego wizerunku, zamawiając kilka portretów ${ }^{20}$.

Dysponujemy kilkoma źródłami dla odtworzenia przebiegu trasy peregrynacji edukacyjnej młodych Zamoyskich. Przede wszystkim są to trzy diariusze. Najwcześniejszy z nich obejmuje lata 1697-1698 ${ }^{21}$. Poprawność atrybucji autorstwa powyższego dziennika podróży Michałowi Zamoyskiemu potwierdza porównanie charakterystycznego pochyłego duktu pisma diariusza oraz jego listów. Pewna przesłanka pozwala na domniemanie istnienia jeszcze innych relacji przesyłanych do kraju, gdyż najmłodszy z braci Zamoyskich usprawiedliwiał się z przerw w spisywaniu dziennika: „Wielki mi smutek i żałość przyniosła, kiedy WM Paniej gniew na mnie o nie wypisowanie diariuszu, któregom ja dotychczas [...] nie wypisował"22. Także Tomasz kilkukrotnie obiecywał matce informowanie o postępach podróży w pisanym przez siebie diariuszu ${ }^{23}$. Być może miał na myśli listy cyklicznie przesyłane do kraju. Kolejny diariusz jest najpełniejszym opisem podróży na odcinku Ingolstadt-Bruksela ${ }^{24}$. Porównanie pisma sugeruje, że obydwa diariusze zostały sporządzone tą samą ręką, co zdecydowanie wskazuje na autorstwo Michała Zamoyskiego. Trzeci z diariuszy zawiera głównie opis pobytu w Paryżu (1-5 I 1699) oraz sporządzone

19 J. K. Kochanowski, Dzieje Akademii Zamojskiej (1594-1784), Kraków 18991900, s. 240-241; R. Malinowska, Historia rodu Zamoyskich, [w:] Zamoyscy w Jabtoniu, red. A. Cebulak, M. Wikło, Jabłoń 2010, s. 30.

${ }^{20} \mathrm{~J}$. Zamoyski, Zbiory Zamoyskich w Klemensowie, [w:] Z dziejów kolekcjonerstwa na Lubelszczyźnie, red. J. Kowalczyk, Lublin 1989, s. 42-43.

${ }^{21}$ Biblioteka Narodowa w Warszawie (dalej cyt.: BN), rkps Biblioteki Ordynacji Zamoyskich (dalej cyt.: BOZ) 1466; Dyariusz podróży i pobytu za granica Michata Zdzistawa Zamoyskiego w latach 1697-1698.

${ }^{22}$ Archiwum Główne Akt Dawnych w Warszawie (dalej cyt.: AGAD), Archiwum Zamoyskich (dalej cyt.: AZ), 549, s. 14-15; Marcin Zamoyski do matki, Praga 2 III 1698.

${ }^{23}$ AGAD, AZ 547, s. 42, 60; Ingolstadt 13 IV 1698; Amsterdam 24 X 1698.

${ }^{24}$ BN, rkps 6891, k. 5-12v, Dyariusz po odjeździe naszym z Ingolsztadu (1698). 
wówczas notatki z wykładów i dysput ${ }^{25}$. Cennym źródłem dla odtworzenia przebiegu peregrynacji jest zbiór listów wysyłanych przez braci z zagranicy do matki. Jego wartość uwydatnia się szczególnie na tych etapach Grand Tour, których nie opisują dzienniki. Na marginesie podjętego tematu warto zaznaczyć, że zachowały się również pochodzące z tego czasu listowne sprawozdania Zofii Bronikowskiej, ochmistrzyni Marianny Teresy Zamoyskiej, siostry trzech braci Zamoyskich, w których zdawała relacje z jej pobytu i nauki we wrocławskiej szkole urszulanek, kierując je do Anny Franciszki z Gnińskich ${ }^{26}$.

Celem Grand Tour Zamoyskich było uzupełnienie edukacji rozpoczętej w kraju oraz zwiedzanie państw europejskich odgrywających kluczową rolę w polityce i kulturze kontynentu. Europejski wojaż był również zalecanym wprost przez statut ordynacji zamojskiej elementem wykształcenia przyszłych ordynatów ${ }^{27}$. Po zakończeniu edukacji domowej pierwszym etapem zdobywania wykształcenia w kraju była nauka w Akademii Zamojskiej. 17 X 1689 roku do metryki studentów wpisano równocześnie wszystkich czterech braci Zamoyskich (najstarszy Jan zmarł wkrótce potem). Z uwagi na bardzo młody wiek (Tomasz miał wówczas dziesięć lat, a młodsi Michał i Marcin odpowiednio dziewięć i osiem) zapisano ich na niższy poziom nauczania (classes inferiores) ${ }^{28}$. Wkrótce miejscem ich nauki stał się Kraków.

W krajowej edukacji młodych Zamoyskich poważną rolę odegrali jezuici. W Krakowie bracia uczyli się pod okiem Sebastiana Piskorskiego, kanonika krakowskiego i prepozyta-infułata ołyckiego, wyznaczonego w 1682 roku na komisarza królewskiego w sporze między Akademią Zamojską i biskupem chełmskim ${ }^{29}$. Donosił on w listach o ich przykładnej

${ }_{25}$ BN, rkps BOZ 1455; Dyariusz zajęć Michata Zamoyskiego bawiącego na naukach w Paryżu w 1699.

${ }^{26}$ B. Popiołek, Peregrynacje edukacyjne i poznawcze w źródtach czasów saskich, [w:] Polski Grand Tour..., s. 51-52.

27 Statuta Ordynacji Zamojskiej od r. 1589-1848, Warszawa 1902, s. 17-18.

${ }^{28}$ Album studentów Akademii Zamojskiej (1595-1781), opr. H. Gmiterek, Warszawa 1994, s. 303.

${ }^{29}$ J. Wadowski, Wiadomość o profesorach Akademii Zamojskiej, Warszawa 1899-1900 , s. 140 . 
nauce i pobożności ${ }^{30}$. W 1691 roku wszystkich trzech braci Zamoyskich wymieniono w liczbie uczniów krakowskich szkół nowodworskich, gdzie studiowało wtedy wielu synów polskiej magnaterii ${ }^{31}$. Jednak już w 1692 roku, z woli matki, powrócili oni do Zamościa, aby uczyć się na szczeblu akademickim, w jednej z klas wyższych (classes superiores): „Anna Zamoyska vidua [...] filios ad latus suum ex academia Cracoviensis ad Academiam Zamoscensis revocavit" 32 .

Kolejnym etapem wykształcenia Tomasza i jego młodszych braci było braniewskie kolegium jezuickie (od 1695 roku). Zamoyscy, liczący sobie wtedy odpowiednio siedemnaście, szesnaście i piętnaście lat, wpisali się do albumu uczniów (26 XI 1695) do klasy filozofii. Tomasz, Michał i Marcin nie byli pozbawieni służby odpowiedniej do ich wysokiego urodzenia. Razem z nimi figuruje tam również Aleksander Luberski, który uda się później razem z Zamoyskimi w podróż. Być może do orszaku młodych ordynatów należeli również, immatrykulowani tego samego dnia, Krzysztof Odrycki oraz Jacek Niewieszczyński ${ }^{33}$. Luberski był wcześniej uczniem Akademii Zamojskiej wpisanym do metryki na rok 1694 jako Franciszek Walerian Lubarski, palatinatus Russiae ${ }^{34}$. Figuruje również z Zamoyskimi w Ingolstadt jako ich famulus ${ }^{35}$. Franciszek Luberski, który pisał się ze wsi Ruble (Poręby) w powiecie pińskim, nosił w 1713 roku tytuł podczaszego mielnickiego ${ }^{36}$. Został on później oficjalistą V ordynata - Tomasza - który korzystał z jego usług w wielu sprawach ${ }^{37}$. Celem pobytu w braniewskim kolegium była przede wszystkim nauka języka niemieckiego, przygotowująca podskarbiców do planowanego Grand Tour. Według zapisów

30 AGAD, AZ 1385, Sebastian Piskorski do Anny Zamoyskiej, Kraków 1 I 1692.

${ }^{31} \mathrm{H}$. Barycz, Historia szkót nowodworskich od zatożenia do reformy H. Kottątaja, Kraków 1988, s. 231.

32 Archiwum Państwowe w Lublinie (dalej cyt.: APL), Kolegiata Zamojska (dalej cyt.: KZ), sygn. 414 (Acta Capitulorum Generalium ... ab Anno 1711 die 4 julii ad 1749 annum), k. 6.

33 G. Lühr, Die Schüler des Braunsberger Gymnasiums von 1694 bis 1776, „Monumenta Historiae Warmiensis”, Bd. 12, Braunsberg 1934, s. 15 (nr 117-122).

34 Album studentów Akademii Zamojskiej..., s. 311.

35 P. Czaplewski, Polacy na studyach w Ingolsztacie, Poznań 1914, s. 84.

36 A. Boniecki, Herbarz polski, t. 15, Warszawa 1912, s. 27-28.

37 J. K. Kochanowski, op. cit., s. 202. 
w aktach kolegiaty zamojskiej mieli oni przebywać w Braniewie ponad rok, a dokładnie około czternastu miesięcy, od dnia św. Katarzyny do święta św. Jana Chrzciciela (29 IV 1685 - 24 VI 1686) ${ }^{38}$. Być może okres przed podjęciem nauki w braniewskim kolegium jezuickim był poprzedzony nauką języka niemieckiego u prywatnych nauczycieli. W trakcie pobytu na Warmii udali się również na wycieczkę turystyczno-poznawczą. Z opiekunem Mikołajem Kamieńskim wybrali się do Fromborka i dalej, żeglując po Zatoce Gdańskiej, do Gdańska (kwiecień 1696), gdzie zwiedzali zabytki ${ }^{39}$. Do Zamościa powrócili w końcu czerwca lub w początkach lipca 1696 roku. Jezuita Jan Sierakowski został wówczas ich opiekunem ${ }^{40}$.

Ważną rolę, jako nieoficjalny guwerner-wychowawca młodych podróżników, odegrał Jan Krukowiecki (1664-1701), profesor retoryki i poetyki w kolegium jezuickim w Grudziądzu oraz misjonarz dworski, który jednak z powodu choroby opuścił swoich podopiecznych przebywających jeszcze za granicą i wkrótce po powrocie do Zamościa zmarł (27 III 1701) ${ }^{41}$. Preceptorem młodych Zamoyskich został doświadczony guwerner Jan Kamocki, który w latach osiemdziesiątych i dziewięćdziesiątych XVII wieku przynajmniej trzykrotnie wyjeżdżał za granicę jako opiekun peregrynantów $^{42}$. Kamoccy h. Jelita byli szeroko rozrodzeni w ziemi łęczyckiej i sieradzkiej. Znanych jest kilku Kamockich tego imienia ${ }^{43}$. Opiekun młodych magnatów w listach podróżnych był określany przez swoich podopiecznych jako „Pan łowczy”, jednakże żaden z Kamockich nie pełnił urzędu łowczego w województwach łęczyckim i sieradzkim. Członkowie tego rodu występowali tam zaś dość często jako rzekomi urzędnicy ${ }^{44}$.

${ }^{38}$ APL, KZ, sygn. 414, k. 7-8.

39 A. Kucharski, Theatrum peregrinandi. Poznawcze aspekty staropolskich podróży w epoce późnego baroku, Toruń 2013, s. 44-45.

${ }^{40}$ F. Stopniak, Dzieje kapituty zamojskiej, Lublin 1962, s. 122-123.

${ }^{41}$ Encyklopedia wiedzy o jezuitach na ziemiach Polski $i$ Litwy 1564-1995, opr. L. Grzebień, Kraków 2004, s. 334.

42 A. Markiewicz, Podróże edukacyjne w czasach Jana III Sobieskiego. Peregrinationes Jablonovinae, Warszawa 2011, s. 252-256.

43 A. Boniecki, Herbarz Polski, t. 9, Warszawa 1906, s. 214-215.

${ }^{4}$ Urzędnicy województw tęczyckiego i sieradzkiego XVI-XVIII wieku. Spisy, opr. E. Opaliński i H. Żerek-Kleszcz, Kórnik 1993, s. 259. 
Podróż rozpoczęto w Warszawie, „po szczęśliwej inauguratiej Friderici Augusti R. Poloniae" ${ }^{45}$. Młodzi Zamoyscy wzięli udział w elekcji z województwem bracławskim, w końcu czerwca 1697 roku, ale w spisie elektorów Augusta II Mocnego odnotowano tylko Michała i Marcina ${ }^{46}$. Michał Zamoyski zanotował jednak w diariuszu, że wszyscy trzej bracia brali udział w elekcji króla Augusta II „cuique electionis spólnie z rodzonemi memi asystowałem" ${ }^{47}$. Z kraju wyruszono więc najpewniej pod koniec pierwszej połowy lipca 1697 roku. Bracia wyruszyli razem, ale Marcin powrócił później ze Śląska do Zamościa i pozostał tam przynajmniej do 30 IX 1697 roku, co potwierdza wzmianka w pamiętniku rosyjskiego posła Borysa Szeremietiewa informująca o powitaniu posła w Zamościu przez „syna jejmości Pani Podskarbiny, Pana Zamojskiego" ${ }^{48}$. Jezuita Jan Krukowiecki został wyznaczony na opiekuna później, już po wyjeździe Zamoyskich z Warszawy i dopiero po wysłaniu listów z prośbą o pozwolenie udania się przez niego w podróż do Pragi, a potem do Rzymu ${ }^{49}$. Marcin Zamoyski wyjechał ostatecznie dopiero w końcu roku, docierając do Pragi 11 XII 1697 roku ${ }^{50}$. Jego pierwszy własnoręczny list do matki nosi jeszcze późniejszą datę ${ }^{51}$.

Po wyjeździe z Warszawy latem 1697 roku orszak Zamoyskich posuwał się niespiesznie, zwiedzając po drodze pałac w Radziejowicach i zamek królewski w Rawie Mazowieckiej. Następnie jechano przez Wolbórz i Piotrków Trybunalski, w którym podziwiano zamek „bardziej kamienicy niż do zamku podobien". Zanotowano, że miasto było miejscem obrad trybunału koronnego, odbywającego się najczęściej na ratuszu. Michał Zamoyski podkreślał dużą rolę trybunału koronnego, który „post festum

45 BN, rkps BOZ 1466, k. 1.

${ }^{46}$ O. Pietruski, Elektorów poczet, którzy niegdyś gtosowali na elektów najjaśniejszych Królów Polskich, Lwów 1845, s. 427.

${ }^{4}$ BN, rkps BOZ 1466, k. 1.

48 F. Sielicki, Podróż bojarzyna Borysa Szeremietiewa przez Polskę i Austrię do Rzymu oraz na Malte (1697-1698), Wrocław 1975, s. 216.

49 Dwa listy zawierające taką prośbę, skierowane do generała zakonu jezuitów, zostały napisane w Zamościu 6 i 18 XI 1697; A. P. Bieś, L. Grzebień, M. Inglot, Polonica w Archiwum Rzymskim Towarzystwa Jezusowego, t. 1: Polonia, Kraków 2002, s. 302.

${ }^{50}$ H. Gmiterek, op. cit., s. 294.

${ }^{51}$ AGAD, AZ 549, s. 4-5, Praga 25 I 1698. 
Francisci Confessoris zaczyna się i odprawuje się aż do Wielki Nocy, wielkopolskie i pruskie tam się sądzą sprawy" ${ }^{2}$. Następnie dojechano do Częstochowy. Młodym Zamoyskim najbardziej zaimponowały bogate zdobienia i wyposażenie sanktuarium:

Obras ex munificentia tak postronnych panów, jako ex liberalitate Polaków znacznie ubogacony. Monstrancja wielce bogata przyozdobiona diamentem wojewody sieradzkiego Przeremskiego, który w koronie jest 30000 talerów szacowany. Dokoła jest trzy tysiące, rachują, diamentów, po drugi stronie rubinami przyozdobiona ${ }^{53}$.

Z Częstochowy udano się do Ołoboku, notując na kartach diariusza pierwszą datę (wigilia wspomnienia św. Anny, czyli $25 \mathrm{VII}$ ). Zatrzymano się na trzy dni w klasztorze, gdzie urząd ksieni sprawowała ciotka peregrynantów Konstancja Gnińska. Stąd przez Oleśnicę orszak podróżny stanął w Trzebnicy, oglądając grób św. Jadwigi śląskiej oraz jej relikwie. 30 VII podróżnicy dotarli do Wrocławia. Stolica Śląska wywarła duże wrażenie na autorze dziennika podróży, który - przytaczając historię miasta - określił je słowami: „Miasto to jest piękne, caput, lumen, sol et oculus Silesiae a Vladislao czeskiego książęcia i króla imię wzięło". Czas upływał im na zwiedzaniu licznych kościołów z katedrą na czele. Już na początku sierpnia od kompanii odłączył się powracający do Zamościa Marcin, którego starsi bracia odprowadzili do Trzebnicy i powrócili do Wrocławia. Zanotowano też ciekawy epizod związany ze zmianą stroju na cudzoziemski i wielość zwiedzanych obiektów architektury, zarówno sakralnej, jak i świeckiej: „jeździliśmy tak do kościołów, jako też do ogroda jednego na samych konsztach wodnych będącego" 54 .

W dalszą drogę do Pragi udano się 11 VIII. W Kłodzku („Glac”) przekroczono granicę śląsko-czeską i orszak Zamoyskich stanął w Nachod („oppidum Nahut”) 55 . Dla peregrynantów miejscowość ta była godna zapamiętania z uwagi na gospodę, w której zatrzymał się król Jan Kazimierz

\footnotetext{
52 BN, rkps BOZ 1466, k. 1v-2.

53 Ibidem, k. 2v.

${ }^{54}$ Ibidem, k. 3-5.

55 H. Gmiterek, op. cit., s. 295.
} 
po abdykacji, podczas swojej podróży do Francji w 1669 roku. Oglądano drewnianą tabliczkę ze złoconą inskrypcją: "Jan Kazimierz nocował u mnie" ${ }^{56}$. Napis ten stał się jednym z ważniejszych śląskich poloników. Podobne znaleziska zbieracze polskich pamiątek notowali gorliwie jeszcze w XIX wieku ${ }^{57}$.

Do Pragi orszak przybył 17 VIII. Blisko siedmiomiesięczny pobyt w stolicy Czech poświęcono na dokładne zwiedzanie miasta i okolic, zawieranie znajomości oraz studia ${ }^{58}$. Preceptor młodych Zamoyskich podkreślał ich pilną naukę na lekcjach geografii i tańca - „kart nie grają, ale nauk pilnują" 59 . Dokładny program edukacyjny znamy z ramowego planu nauki, tzw. connotatio dyspozycyjej i czasu spisanego przez Jana Kamockiego według zaleceń matki peregrynatorów. Pozwala on określić charakter nauki jako studia prywatne pod kierunkiem profesorów języków niemieckiego i francuskiego, retoryki, tańca, muzyki i historii ${ }^{60}$. Wyjazd z Pragi przypadł na koniec zimy (12 III 1698). Orszak podróżny Zamoyskich skierował się na zachód, przejeżdżając przez Pilzno. Pokonanie dystansu do kolejnego miejsca studiów zajęło zaledwie siedem dni. Jechano terenem górzystym, narzekając na trakt wiodący „między samemi skałami wielkiemi przez góry bardzo wysokie" ${ }^{61}$. Po dotarciu do Ingolstadt peregrynanci immatrykulowali się na tutejszej akademii (24 III 1698). Wpisano ich na semestr zimowy roku akademickiego 1697/1698, mimo że przybyli dopiero wczesną wiosną. Z metryki uniwersyteckiej możemy poznać również skład orszaku młodych magnatów: preceptora Jana Kamockiego oraz trzech famulusów (Franciszek Luberski, Kazimierz Winckler i Włoch Tomasz Vagni) ${ }^{62}$.

56 BN, rkps BOZ 1466, k. 5v-6.

57 R. Kincel, U Szlaskich wód, [Racibórz-Katowice 1994], s. 113.

${ }^{58}$ H. Gmiterek, op. cit., s. 296-305.

59 AGAD, AZ 516, s. 17-20; Jan Kamocki do Anny Zamoyskiej, Praga 5 IX 1697.

${ }^{60}$ A. Kucharski, Instrukcja podróżna Anny Zamoyskiej dla synów odbywajacych peregrynacje po Europie na przetomie XVII i XVIII wieku, „Czasy Nowożytne” 2012, t. 25, s. $217,222-224$.

${ }^{61}$ BN, rkps BOZ 1466, k. 94-94v.

${ }^{62}$ Die Matrikel der Ludwig-Maximilians-Universität Ingolstadt-Landshut-München, hrsg von Götz Freiherrn von Pölnitz, München 1939, Bd. 2: 1600-1700, s. 1334. 
Okres pobytu w Ingolstadt był czasem wytężonej nauki. Poza zajęciami na akademii jezuickiej młodzi ordynaci poświęcali wiele uwagi lekturze dzieł historycznych oraz dysputom z dziedziny polityki i ekonomii. Częstym elementem programu dnia był udział w nabożeństwach i obchodach świąt. Czas wolny wykorzystywano na zwiedzanie miasta i odwiedziny przyjaciół. Oglądano także spektakle teatru jezuickiego i ćwiczenia strzeleckie oraz bywano $\mathrm{w}$ ogrodzie akademii, spotykając się z innymi studentami ${ }^{63}$. W trakcie nauki w bawarskiej akademii jezuickiej, na przełomie lipca i sierpnia 1698 roku urządzono wycieczkę krajoznawczą do Austrii. Zwiedzano wówczas Monachium, Augsburg i Salzburg. W ostatnim $\mathrm{z}$ tych miast wysłuchano dialogu w dzień kanonicznego wspomnienia św. Ignacego Loyoli (31 VII). Jednakże głównym celem tej eskapady był Wiedeń, a w zasadzie chęć zobaczenia cara rosyjskiego podróżującego po Europie. Nie udało się jednak zrealizować tego zamierzenia wobec wcześniejszego wyjazdu orszaku carskiego ${ }^{64}$. Informacja ta pozwala dokładniej określić datę przyjazdu do stolicy cesarskiej. Car Piotr I był bowiem przyjmowany przez Leopolda I od końca czerwca 1698 roku, a wyjazd Rosjan nastąpił 25 VII, po prawie miesięcznym pobycie ${ }^{65}$. Zamoyscy musieli więc przybyć do Wiednia po tej dacie.

Po ostatecznym opuszczeniu Ingolstadt (17 VIII 1698) udano się na zachód przez ziemie cesarskie. W diariuszu dużo uwagi poświęcono Augsburgowi. Podkreślano jego status wolnego miasta cesarskiego oraz potężnie ufortyfikowane mury miejskie. Opisano także sytuację ekonomiczną $\mathrm{z}$ naciskiem na wiodącą rolę rzemiosła złotniczego i problemy handlowe. Podnoszono również konflikty wyznaniowe między katolikami i luteranami. Zwiedzano katedrę i kościoły, oddając cześć zgromadzonym tam relikwiom $^{66}$. Ten aspekt kultu miał szczególne znaczenie podczas wizyty w po-

${ }^{63} \mathrm{BN}, \mathrm{rkps} \mathrm{BOZ} 1466, \mathrm{k} .101-103$.

${ }^{64}$ AGAD, AZ 546, s. 43-44; Tomasz, Michał i Marcin Zamoyscy do Jana Chryzostoma Pieniążka, Paryż 17 IV 1699. List ten zawiera skrótowy opis całej podróży Zamoyskich do momentu jego napisania.

65 W. Serczyk, Piotr Wielki, Wrocław 2003, s. 77-83.

${ }^{66}$ BN, rkps 6891, k. 5-6v. 
dzielonym konfesyjnie mieście. W czasie pobytu w Augsburgu zamówiono nową karetę oraz uzupełniono ekwipaż podróżny ${ }^{67}$.

Posuwając się na zachód przez prowincję Badenia-Wirtembergia, podróżnicy napotykali kolejne nowe dowody trudnej sytuacji katolików, stanowiących wyznaniową mniejszość. W Ulm pisano „prócz codziennego dla swawolnego pospólstwa życia niebezpieczeństwa nie godzi się choć umierającego słuchać spowiedzi i jemu służyć kapłanowi”. W Stuttgarcie mogli uczestniczyć we mszy jedynie w prywatnej kaplicy posła francuskiego. Atmosfera sporów konfesyjnych była dodatkowo potęgowana przez rzucające się w oczy efekty konfliktów polityczno-wojskowych, a w szczególności widok ruin miasta Durlach, stolicy księstwa badeńskiego, kompletnie zniszczonego w 1689 roku przez wojska francuskie ${ }^{68}$.

Przekroczywszy Ren, wjechano na teren Francji. Przejeżdżając kolejne prowincje, często podkreślano żyzność ziem i wielość bogactw naturalnych. Jednak w drodze przez regiony Lotaryngii, Szampanii czy Pikardii nie pomijano widocznych zniszczeń wojennych czy też zubożałych lub całkowicie wyludnionych wsi, będących czytelnym symptomem poważnego kryzysu gospodarczego ${ }^{69}$. Po opuszczeniu Reims, gdzie Zamoyscy zwiedzali gotycką katedrę oraz oglądali zgromadzone w jej skarbcu relikwie, zatrzymali się na dłużej w Compiègne, aby obserwować przegląd wojska, któremu poświęcono bardzo wiele czasu (pobyt trwał aż dwa tygodnie, od 7 do 21 IX 1698). W diariuszu dzień po dniu opisywano przebieg manewrów. Drobiazgowo odnotowywano ruchy poszczególnych formacji wojskowych. Szczególną uwagę poświęcano użyciu broni palnej i artylerii ${ }^{70}$.

Przez pogranicze francusko-flamandzkie (Cambrai, Valenciennes) podróżnicy wkroczyli na ziemie pozostające pod władzą króla hiszpańskiego Karola II. Ten etap podróży przysporzył dobrych okazji do zapoznania się z historią wojskową. Mijane twierdze były niemymi świadkami często toczonych wojen francusko-hiszpańskich. W Mons wspominano o długim oblężeniu francuskim. W Halle zwiedzano słynne sanktuarium maryjne:

${ }^{67}$ AGAD, AZ 547, s. 56-57; Tomasz Zamoyski do matki, Augsburg 22 VIII 1698.

${ }^{68} \mathrm{BN}$, rkps 6891, k. 6v-7.

${ }^{69}$ M. Kamecka, „Do cudzych krajów”..., s. 129-130.

${ }^{70}$ BN, rkps 6891, k. 10-12. 
Jest miasto nieprzednie, ale ma wielki zaszczyt i skarb z statui N[ajświętszej] Matki Boskiej od lat cudami słynąca 400. Cuda tego obrazu extant in Iusto Lipsio napisane. Drugie w kościele malowane srebrami, marmurami ozdobione. Wotum osobliwe Justi Lipsii i pióro jego, którym księgi swoje pisał ${ }^{71}$.

Relacja z tego etapu peregrynacji kończy się w Brukseli obietnicą sporządzenia dalszego ciągu. Nie wiadomo jednak czy zrealizowano ten zamiar. Pobyt w stolicy Niderlandów Hiszpańskich okazał się bardzo krótki i był jedynie przystankiem w drodze do Paryża:

My dnia jutrzejszego w małym poczcie wyjeżdżamy do Anterfiej, stamtąd niektóre porty i fortece nad morzem obaczywszy przez Holandię do Francyi. Cokolwiek zaś ta peregrynacyja nam przyniesie raritates oddamy racyją podróży naszej i profit ${ }^{72}$.

Profitem, o którym pisano, było podziwianie architektury militarnej na terenie południowej części Niderlandów oraz Holandii. Pobyt w tej części Europy przypadł na październik i początek listopada 1698 roku. Zwiedzanie Niderlandów miało charakter dość pospieszny. Korzystano z wygodnego i szybkiego środka lokomocji, jakim były łodzie poruszające się po licznych kanałach śródlądowych:

Wybrawszy się z Bruxel do Holandiej i część niemałą Belgii zwiedziwszy, samą zaś Holandię prędką drogą bo samemi tylko wodami i nawami zlustrowawszy (której prowincyjej piękności, wielkości miast i bogactw w całej Europie największych opisać niepodobna).

Ostatecznie ta część podróży znalazła swoje ukoronowanie w stolicy Holandii „mieście nieopisanej piękności i dostatków”. Krótki pobyt w tej metropolii zaznaczył się również rozwinięciem zainteresowań bibliofilskich. Tomasz bywał w amsterdamskich księgarniach, wybierając dzieła do ro-

${ }^{71}$ Ibidem, k. 12v.

72 AGAD, AZ 547, s. 58; Tomasz Zamoyski do matki, Bruksela 13 X 1698. 
dzinnej biblioteki. Prosił o subwencje pieniężne na ten cel, wyrażając nadzieję, że matka „każe je na ozdobę domu naszego zapłacić”’3.

Jesienią 1698 roku orszak zatrzymał się w Paryżu. Z tego okresu pochodzą obszerne zapiski Michała Zamoyskiego, dokumentujące przebieg nauki oraz zawierające historyczno-geograficzny opis Francji ${ }^{74}$. W początkach następnego roku urządzono wycieczkę do Wersalu w związku z pasowaniem kawalerów Orderu Ducha Świętego. Diariusz opisujący pobyt w królewskiej rezydencji jest pełen zachwytów dla architektury i wystroju barokowego założenia pałacowego w Wersalu ${ }^{75}$. Listy paryskie zawierają szereg faktów z życia naukowego i codziennego podróżników. Powtarzają się tam także skargi na jezuitę Jana Krukowieckiego i prośby o jego odwołanie ${ }^{76}$.

Niemalże koniecznym, chociaż w staropolskiej praktyce podróżnej często opuszczanym etapem Grand Tour była wycieczka do Anglii. W trakcie swojej wielkiej podróży Zamoyscy bawili tam nawet dwukrotnie. Najpierw kanał La Manche pokonał samotnie Tomasz, który w Londynie spędził cały maj 1699 roku $^{77}$. Nie towarzyszył mu guwerner, który musiał opiekować się jego chorym bratem ${ }^{78}$. Michał i jego młodszy brat zawitali tam dopiero późnym latem 1699 roku. Rozdzielenie wizyt braci było spowodowane wspomnianą chorobą jednego $\mathrm{z}$ nich oraz planowanym wcześniejszym powrotem do kraju Tomasza w związku ze sprawami majątkowymi ordynacji zamojskiej. W drodze powrotnej z Anglii młodsi bracia, pod opieką Kamockiego, po raz drugi bawili w Niderlandach. Tym razem jednak bardzo krótko zwiedzano Holandię i Niderlandy Hiszpańskie. Wyjazd z Paryża na Wyspy Brytyjskie nastąpił zapewne około połowy sierpnia 1699 roku, gdyż jeszcze w początkach tego miesiąca wszyscy trzej bracia przebywali razem.

${ }^{73}$ Ibidem, s. 60-61; Amsterdam 24 X 1698.

${ }^{74}$ M. Kamecka, „Do cudzych krajów”..., s. 124-125.

75 BN, rkps BOZ 1455, s. 1-8; Wersal 1-5 I 1699.

76 A. Markiewicz, Podróże edukacyjne w czasach Jana III Sobieskiego, s. 55-56.

77 AGAD, AZ 546, s. 32; Tomasz Zamoyski do matki, Paryż 17 VII 1699.

${ }^{78}$ AGAD, AZ 516, s. 21-22; Jan Kamocki do Anny Zamoyskiej, Paryż 17 VII 1699. 
Zaledwie jeden niedatowany list przynosi informacje o pobycie w Londynie (wrzesień 1699). W stolicy Anglii Zamoyscy planowali kupno książek oraz „inszych galanteryi”. Polscy turyści zachwycali się eksponatami kolekcji królewskich. W znajdującym się w Tower of London skarbcu monarchów angielskich ich uwagę zwróciły insygnia królewskie, a szczególnie korony inkrustowane szlachetnymi kamieniami (diamentami, rubinami i perłami) nieoszacowanej wartości. Oglądali nagrobki w panteonie królewskim w Opactwie Westminsterskim: „Lustrując monumenta królów napadliśmy na jedno świeżo położone. Te było jednego starca o stu pięćdziesiąt lat, który kilką przed nami miesięcy drugiego nie dokończył saeculum"79. Podczas pobytu w Londynie realizowali klasyczny program krajoznawczy, obejmujący najważniejsze obiekty sakralne, królewskie i publiczne. Podążali utartą trasą zwiedzania uczęszczaną przez wielu cudzoziemców, w tym także Polaków. Skupili się również, podobnie jak inni Polacy, na najpopularniejszych zabytkach angielskiej sztuki i architektury ${ }^{80}$. Widzieli również menażerię londyńską, w której szczególne wrażenie zrobił na nich widok egzotycznych drapieżników: „Widzieliśmy lwów, tygrysów, lampartów i insze bestyje". Arsenał londyński zadziwił podróżników wielką obfitością i różnorodnością zgromadzonej broni, głównie palnej, a w mniejszej mierze także białej, wśród której wymieniali 150 tysięcy muszkietów, pistolety, fuzje oraz szpady. Nie tylko aspekt militarny zbrojowni mieszczącej się w Twierdzy Tower przykuł uwagę zwiedzających, lecz także wdzięczne kształty elementów i ornamentów architektonicznych: „Są bramy, kolumny, arcus triumphales, słońca, węże, smoki i insze kształtnie z ułożenia wyrobione machiny" 81 .

Kolejna wzmianka o pobycie w Londynie pojawia się przy okazji próśb o subsydia pieniężne na spłatę pożyczek zaciągniętych na kupno książek i innych utensyliów w Amsterdamie i nad Tamizą: „w Londrze zaś na kredyt dwa zygarki wzięliśmy, za które 45 czerwonych złotych przychodzi”"

79 AGAD, AZ 546, s. 74-75; Michał i Marcin Zamoyscy do matki, Londyn [b.d.].

${ }^{80}$ B. M. Puchalska, Obraz dworów zachodnioeuropejskich w polskiej literaturze pamiętnikarskiej XVI i XVII wieku, Białystok 2000, s. 50-51.

${ }^{81}$ AGAD, AZ 546, s. 75-76; Michał i Marcin Zamoyscy do matki, Londyn [b.d.].

${ }^{82}$ AGAD, AZ 546, s. 26-27; Michał i Marcin Zamoyscy do siostry, Haga 17 X 1699. 
Zapis ten świadczy, że młodzi Zamoyscy interesowali się nie tylko literaturą, ale również zegarkami mechanicznymi, coraz bardziej rozpowszechniającymi się w Europie XVII wieku, które były obiektem powszechnego zainteresowania podróżników.

Powrót z Anglii wyglądał następująco:

\begin{abstract}
Wyjechaliśmy z Angliej w pół czwartej godziny odbiliśmy morze i na francuskich stanęliśmy granicach. Stamtąd jadąc ku Holandiej przez Flandrią wielkie mieliśmy ukontentowanie widzieć miasta, które historycy często wspominają jako to Dunkierk, Nieport, Ostenda, Brusz, Gan i wiele innych, które przez wojny różne sławne są. Tam widzieliśmy pola, gdzie obozy francuskie jako koligackie stawały i gdzie różne batalie były ${ }^{83}$.
\end{abstract}

Podczas przejazdu przez Holandię na dłużej zatrzymano się w Hadze (ok. 11-21 X 1699). Z uwagi na przyjazd króla angielskiego i stadhoudera Holandii Wilhelma III Orańskiego do Hagi przybyło mnóstwo gości. Z tego względu peregrynanci mieli wielkie kłopoty ze znalezieniem wolnej austerii i narzekali na drożyznę panującą w mieście. Przez ziemie Holandii i Flandrii udano się wprost do Paryża, gdzie zawitano „po zwyciężonych holenderskich i flanderskich podróżach”. Była to forsowna podróż, niesprzyjająca zwiedzaniu z powodu słotnej pogody jesiennej ${ }^{84}$.

W Paryżu kontynuowano naukę. W listach donoszono o przybywających do miasta Polakach i spotkaniach z nimi, np. trzech braciach Radziwiłłach - Janie Mikołaju, Marcinie i Mikołaju Faustynie - jadących w dwóch karetach z paradnym orszakiem 12 ludzi noszących liberie ${ }^{85}$. Do programu pobytu w wymiarze formacji kulturalnej należało bywanie na spektaklach teatralnych. Z relacji Stanisława Krasińskiego wiemy, że 8 XI 1699 roku Zamoyscy towarzyszyli mu podczas oglądania spektaklu opery Bellerofont Jeana Baptiste Lully' ego $^{86}$. W listach umieszczano też in-

${ }^{83}$ AGAD, AZ 546, s. 34-35; Michał i Marcin Zamoyscy do matki, Antwerpia 3 X 1699.

${ }^{84}$ AGAD, AZ 516, s. 27-28; Jan Kamocki do Anny Zamoyskiej, Haga 21 X 1699.

${ }^{85}$ AGAD, AZ 548, s. 41-42; Michał Zamoyski do matki, Paryż 18 X 1699.

${ }^{86}$ S. Krasiński, Compendium dyaryuszu niemieckiey, francuskiey, angielskiey, olenderskiey peregrynacyi, Warszawa $1705, \mathrm{k} . \mathrm{D}_{2}$. 
formacje z życia codziennego, np. obawę przed epidemią jakiejś groźnej choroby zakaźnej, na którą zapadli towarzysze podróży Krasińskiego ${ }^{87}$.

Jeszcze w pierwszej połowie 1699 roku Michał Zamoyski, przebywający wówczas w Paryżu, otrzymał w wyniku starań swej matki starostwo gniewskie i międzyłęskie. Urzędy te uzyskał 25 VI wskutek rezygnacji królowej-wdowy Marii Kazimiery Sobieskiej, piastującej je po śmierci króla Jana III ${ }^{88}$. Nowe godności oznaczały poważny awans w hierarchii urzędniczej oraz znaczny wzrost prestiżu młodego Zamoyskiego, gdyż starostwo gniewskie było wówczas najbogatszą królewszczyzną województwa pomorskiego ${ }^{89}$. Matka peregrynantów podejmowała w pierwszym półroczu 1699 roku energiczne działania na rzecz umocnienia pozycji swoich synów bawiących za granica, starając się o zaaranżowanie mariażu Tomasza Józefa. Napotkała jednak w tym względzie poważnego rywala w osobie Jana Radziwiłła, który - przerywając swoją podróż edukacyjną - zabiegał o rękę córki wojewody kaliskiego Władysława Przyjemskiego. Wobec śmierci wojewody oraz silnej konkurencji został jednak zmuszony do rezygnacji ${ }^{90} . Z$ jego korespondencji wiemy, że postrzegał on najstarszego z braci Zamoyskich jako poważnego przeciwnika w tych konkurach głównie z powodu matrymonialnych planów Anny Zamoyskiej:

Pan ordynat Zamoyski, ów natarczywy konkurent, niech co chce ad famam et iactantiam głosi już na tych godach zapewne nie będzie bo Ich Mść obojej strony matki w niechęci rozjechały się z sobą et alia plura zaszły co mam ex occulatis testibus ${ }^{91}$.

Po powrocie z Anglii do Paryża, jesienią 1699 roku, bracia rozdzielili się. Młodsi, pod opieką Kamockiego, pozostali we francuskiej stolicy, natomiast Tomasz udał się do Wrocławia. Powrót i przynajmniej krótki pobyt

${ }^{87}$ AGAD, AZ 548, s. 41-42; Michał Zamoyski do matki, Paryż 18 X 1699.

88 P. Czaplewski, Senatorowie świeccy, podskarbiowie i starostowie Prus Królewskich 1454-1772, Toruń 1921, s. 83-84.

${ }^{89}$ T. Zielińska, Magnateria polska epoki saskiej..., s. 115.

90 A. Rachuba, Radziwitt Jan Mikotaj, Polski Słownik Biograficzny (dalej cyt.: PSB), 1987 , t. 30, s. 200.

${ }^{91}$ AGAD, Archiwum Radziwiłłów, IV, 192, s. 2; Jan Radziwiłł do Karola Radziwiłła, Miedniewice 26 III 1699. 
w kraju musiał mieć związek z kwestią jak najszybszego objęcia przez niego ordynacji zamojskiej. Jednakże napięte stosunki i ostre konflikty z opiekunami, którzy otwarcie ingerowali w sprawy ordynacji, zmusiły Tomasza do ponownego wyjazdu do Wrocławia ${ }^{92}$. W tej dwuznacznej sytuacji pisał stamtąd listy do matki, wyrażając swoje rozterki co do dalszego przebiegu podróży. Powrót do Paryża wydawał mu się zbyt czasochłonny i drogi. Wobec zbliżających się obchodów roku jubileuszowego wybrał drogę do Rzymu z dłuższym pobytem w Turynie, gdzie faktycznie pozostał „przy dworze tak sławnym będąc księcia sawojskiego" "93.

W początkach grudnia 1699 roku Tomasz był już w Turynie. Kamocki donosił matce przyszłego ordynata, że musiał on na tę podróż zaciągnąć sporą pożyczkę i teraz oczekuje na pieniądze, aby spłacić wierzytelności za „wiwendę, exercitia i inne potrzeby” ${ }^{4}$. Informacje o konieczności zapłacenia za lekcje czy też ćwiczenia rycerskie wskazują, że Tomasz uczył się w Turynie u prywatnych nauczycieli lub w miejscowej Akademii Rycerskiej. W miarę upływu czasu jego sytuacja materialna musiała się pogarszać, gdyż był zmuszony zaciągać kolejne kredyty. Informował, że za 400 talarów zastawił „skrzynią zapieczętowaną z sukniami z materiami i inszemi rzeczami"95. Problemy finansowe, i to dużo wcześniej, dotknęły również grupę pozostałą w Paryżu. Narzekano na niemożność uregulowania długów zaciągniętych na „łóżko, materie i galony”, przewidując uciążliwą przeprawę zimową przez Alpy do Włoch ${ }^{96}$. Była ona jednak długo odkładana ze względu na kłopoty finansowe. Jeszcze w lutym 1700 roku pisano, że będą zmuszeni spędzić kolejne lato w Paryżu z uwagi na wielkie upały we Włoszech. Wyrażano przy tym sugestię, że najlepszym rozwiązaniem byłoby dotarcie do Rzymu na Święta Wielkanocne i wyruszenie w połowie czerwca do Niemiec ${ }^{97}$.

${ }^{92}$ M. Kozaczka, op. cit., s. 44.

93 AGAD, AZ 547, s. 74; Tomasz Zamoyski do matki, Wrocław 22 X 1699.

${ }^{44}$ AGAD, AZ 516, s. 34-35; Jan Kamocki do Anny Zamoyskiej, Paryż 26 XI 1699.

${ }^{5}$ AGAD, AZ 547, s. 78-79; Tomasz Zamoyski do matki, Turyn 12 XII 1699.

96 AGAD, AZ 516, s. 31-32; Jan Kamocki do Anny Zamoyskiej, Paryż 13 XI 1699.

${ }^{97}$ AGAD, AZ 518, s. 152-154; Jan Krukowiecki do Anny Zamoyskiej, Paryż 18 II 1700. 
Nastąpiła jednak zmiana planów i najpierw udano się do kraju, gdzie w Ołoboku doszło do spotkania synów z matką w połowie 1700 roku i konsultacji dalszego przebiegu podróży. Jeszcze ważniejszym powodem czasowego powrotu do Polski były sprawy rodzinne, a w głównej mierze szukanie oparcia w Auguście II podczas walki o pełne prawa podskarbiców koronnych do objęcia ordynacji zamojskiej. Wyposażeni w instrukcję podróżną matki bracia opuścili jesienią ziemie Rzeczypospolitej ${ }^{98}$.

W drugiej połowie października 1700 roku dotarli do Pragi. Dłuższy pobyt w Polsce był spowodowany oczekiwaniem na polepszenie stanu zdrowia ciężko chorego jezuity Jana Krukowieckiego, który „ledwie się co puściwszy w dalszą drogę z nami, pomiarkował się z siłami, że nie mógł wytrwać"99. W początkach listopada Zamoyscy dotarli do Bawarii, jednak pod koniec wojażu po ziemiach niemieckich trapiły ich coraz większe problemy finansowe. Skłaniało to braci do próśb kierowanych do matki o kolejne subsydia pieniężne. Zaznaczano, że posiadane środki nie wystarczą na podróż i utrzymanie w Rzymie, mimo że starają się żyć bardzo oszczędnie. Pod koniec 1700 roku coraz bardziej podupadał na zdrowiu Krukowiecki ${ }^{100}$. Jeszcze w Bawarii informowali listownie o śmierci papieża Innocentego XII i rozpoczętym konklawe ${ }^{101}$.

Przybywając na uroczystości jubileuszowe do Rzymu (początek grudnia 1700), Zamoyscy wpisali się w starszą tradycję osobistego i bezpośredniego świętowania jednej z największych uroczystości Kościoła. Stali się również częścią licznej społeczności polskiej szlachty i magnaterii, która przybyła do Wiecznego Miasta, skupiając się wokół królowej Marii Kazimiery Sobieskiej, która wyemigrowała z kraju w 1699 roku ${ }^{102}$. Po przyjeździe narzekano na pogodę, która wywołała u nich problemy zdrowotne - „aeria zła i zaraźliwa haniebnie i nieprzyzwyczajonym szkodliwa” 103 . Wkrótce po przybyciu Zamoyscy byli na audiencji u nowo wybranego papieża Klemensa XI (19 XII 1700). Zostali przyjęci z „ojcowskim afek-

\footnotetext{
98 A. Kucharski, Instrukcja podróżna Anny Zamoyskiej..., s. 213.

99 AGAD, AZ 547, s. 88; Tomasz Zamoyski do matki, Praga 17 X 1700.

100 Ibidem, s. 91; Tomasz Zamoyski do matki, Augsburg 4 XI 1700.

101 AGAD, AZ 549, Marcin Zamoyski do matki, Augsburg 4 XI 1700.

${ }^{102}$ M. Loret, Życie polskie w Rzymie w XVIII w., Rzym [ok. 1930], s. 196.

103 AGAD, AZ 547, s. 96; Tomasz Zamoyski do matki, Rzym 4 XII 1700.
} 
tem" i otrzymali odpust zupełny na wypadek nagłej śmierci ${ }^{104}$. W styczniu 1701 roku ponownie byli na audiencji u papieża, gdzie prezentowała ich Maria Kazimiera ${ }^{105}$. Podczas pobytu w Rzymie Zamoyscy byli częstymi gośćmi królowej, która darzyła ich „osobliwym respektem”. Towarzyszyli jej podczas spektakli teatralnych, usługując w loży. Serdeczne relacje z wdową po Janie Sobieskim wskazują na załagodzenie sporów wokół ordynacji zamojskiej, które pojawiły się po śmierci ojca młodych Zamoyskich, kiedy to Maria Kazimiera wymusiła na Annie Zamoyskiej oddanie jej w dziedziczne posiadanie dóbr sarnowskich ${ }^{106}$.

Odwiedzali również młodszych synów królowej, Aleksandra i Konstantego. Z młodymi Sobieskimi Zamoyskich łączyły bliskie i częste kontakty. Z zadowoleniem informowali o zaproszeniu na uroczystość wręczenia „królewiczom” Orderu Ducha Świętego. „Cordon Bleu” miał oddawać poseł francuski ${ }^{107}$. Po serii zabiegów dyplomatycznych królowej Marii Kazimiery Ludwik XIV wyraził zgodę na odznaczenie młodych Sobieskich przez swojego ambasadora w Rzymie. Prestiżowa ceremonia odbyła się dnia 13 XII 1700 we francuskim kościele św. Ludwika ${ }^{108}$. Zamoyscy dysponowali nawet poufnymi informacjami o rodzinie Sobieskich. W liście z 9 IV donosili bowiem o planach powrotu młodych Sobieskich do Polski. Pozostali oni jednak w Rzymie aż do początku lata 1701 roku, kiedy to po głośnym skandalu z udziałem kurtyzany Tolli Konstanty Sobieski pojechał do Oławy, a Aleksander pozostał w Rzymie ${ }^{109}$. W początkach 1701 roku Zamoyscy wespół z „królewiczami” Sobieskimi przypatrywali się zabawom karnawałowym. Uczestnicząc w zabawach, młodzi ordynaci dokonali ciekawych obserwacji wyjątkowości tego czasu, łączącego rozrywkę z wymogami ascezy i pobożności:

${ }^{104}$ Ibidem, s. 103; Rzym 24 XII 1700.

105 AGAD, AZ 549, s. 72-74; Marcin Zamoyski do matki, Rzym 15 I 1701.

106 R. Orłowski, op. cit., s. 111.

107 AGAD, AZ 547, s. 100; Tomasz Zamoyski do matki, Rzym 18 XII 1700.

108 M. Komaszyński, Maria Kazimiera d'Arquien Sobieska królowa Polski 1641-1716, Kraków 1984, s. 223.

109 A. Skrzypietz, Królewscy synowie - Jakub, Aleksander i Konstanty Sobiescy, Katowice 2011, s. 370-372. 
Karnawał rzymski mieszał nabożeństwo zwyczajnej wesołości i ze wszelką modestią obserwowane mięsopusty, świętym by samym mogły być divertymentem. Były i maszkary, ale jeno do wieczora i to na kursie, to jest jednej na to destynowanej ulicy, gdzie i konie, i wszyscy dziwnie ubrani śmiech z siebie dobrowolny czynili. Następowały potym bale, to jest tańce w niektórych wielkich domach, ale tam nie każdego puszczano. Dni trwała ośm maszkarada, ale przerywana w piątek, w niedziele i święto nie wolno było ${ }^{110}$.

Młodsi królewicze Sobiescy należeli do najściślejszego kręgu towarzyskiego Zamoyskich w trakcie ich podróży. Na poszczególnych etapach podróży krąg znajomości młodych ordynatów kształtował się głównie pod wpływem czynników etnicznych i edukacyjnych. Obejmował zatem przede wszystkim kolegów, wespół z którymi uczestniczyli w zajęciach naukowych, wśród nich głównie rodaków licznie spotykanych w metropoliach Europy i na trasach przejazdów. Kontakty z Sobieskimi oraz dostojnikami kościelnymi sytuowały ich na szczycie rzymskiej socjety i weszły na trwałe do historii heraldycznej Zamoyskich, którzy „przyjaźń zabrawszy z królewiczami polskiemi, synami Jana, krewnemi swojemi [...] często się wzajemnie wizytowali, w niemniejsze wchodząc przyjaźni z innymi kardynałami i książętami”"111.

Sporą część czasu zagranicznych podróży i pobytów, nie tylko w Rzymie, zajmowała Zamoyskim „publika”, czyli życie towarzyskie, odwiedziny rodaków, uczestnictwo w obiadach i przyjęciach. Ich nazwiska wymieniali inni polscy podróżnicy w efekcie wzajemnych spotkań ${ }^{112} . \mathrm{Z}$ powodu braku diariusza opisującego włoski etap podróży trudno wyrobić sobie zdanie o tym, jak dokładnie młodzieńcy poznali Rzym. Z pewnością zwiedzali wiele kościołów, chociażby przy okazji audiencji papieskich czy ingresu Klemensa XI do bazyliki św. Jana na Lateranie, dla widzenia którego

110 AGAD, AZ 549, s. 82-83; Marcin Zamoyski do matki, Rzym 19 II 1701.

111 S. Duńczewski, Herbarz wielu domów Korony Polskiej i Wielkiego Księstwa Litewskiego, Kraków 1757, cz. 1, s. 250-251.

112 A. Sajkowski, Opowieści misjonarzy, konkwistadorów, pielgrzymów i innych świata ciekawych, Poznań 1991, s. 277. 
opóźnili swój wyjazd ${ }^{113}$. Z zachowanego notatnika Michała Zamoyskiego wynika, że przedmiotem kontemplacji podróżników były dzieła sztuki włoskiej, gdyż znajdujemy w nim wierszowany opis znanej rzeźby Berniniego przedstawiającej Ekstazę św. Teresy ${ }^{114}$.

Uwagę peregrynantów zaprzątały też starania o pozyskanie relikwii. Zabiegi takie były zorganizowanym procesem realizacji złożonego programu ikonograficznego, którego relikwie były ważną częścią od czasów fundacji kolegiaty w Zamościu przez Jana Zamoyskiego ${ }^{115}$. Starania młodych Zamoyskich wpisywały się również w tę politykę mecenatu nad Kościołem oraz dbałości o rodowe sanktuarium. Dzięki pośrednictwu kardynała Giuseppe Sacripante, „przez którego wszystkie idą ekspedycyje duchowne”, uzyskali pozwolenie papieskie na wywiezienie do Polski w całości relikwii jakiegoś świętego. Obiecywali również listownie kolejne zabiegi o fragmenty relikwii innych świętych oraz przywileje dla ołtarza w kolegiacie zamojskiej $^{116}$. Istotnym punktem pobytu w Rzymie były także wytrwałe zabiegi podejmowane w Stolicy Apostolskiej o poparcie starań swego wuja o przeniesienie go na inne biskupstwo. Rzecz dotyczyła brata matki Zamoyskich, ordynariusza kamienieckiego Jana Chryzostoma Gnińskiego, dążącego do uzyskania bardziej intratnego biskupstwa (warmińskiego lub chełmińskiego ${ }^{117}$. Pośrednikiem w rzymskich staraniach jego młodych siostrzeńców był kardynał Giacomo Cantelmo, przedstawiciel papieski w Wiedniu i Szwajcarii oraz nadzwyczajny nuncjusz papieski w Polsce w latach 1687$-1689^{118}$. W kwestii tej Zamoyscy składali wizyty kardynałowi Cantelmo w Rzymie (w styczniu i lutym 1710) oraz podczas pobytu w Neapolu. Cała sprawa zakończyła się jednak fiaskiem.

113 AGAD, AZ 547, s. 130; Tomasz, Michał i Marcin Zamoyscy do matki, Rzym 9 IV 1701.

114 BN, rkps BOZ 1528, k. 279; Manuskrypt szkolny Notata varia obejmuje lata 1695-1701.

115 J. Kowalczyk, Kolegiata w Zamościu, Warszawa 1968, s. 120-122.

116 AGAD, AZ 549, s. 83-84; Marcin Zamoyski do matki, Rzym 19 II 1701.

117 J. Perdenia, Gniński Jan Chryzostom Benedykt, PSB, 1959-1960, t. 8, s. 152-153.

118 V. I. Comparato, Cantelmo Giacomo, Dizionario Biografico degli Italiani, 1975, vol. 18 , s. 267-270. 
Relacjonowali matce także bieżącą sytuację polityczną w Europie w trakcie wojny o sukcesję hiszpańską, działania mocarstw i przebieg kampanii wojennych. Wiadomości na temat pobytu Zamoyskich w Rzymie przynosi również pamiętnik Krzysztofa Zawiszy mieszkającego w Rzymie w okresie od września 1700 do lutego 1701 roku. Musiały go z młodymi ordynatami łączyć dość bliskie stosunki, skoro pisał o nich: „Zamojscy podskarbiowie dobrzy moi kompanistowie". Na odjezdnym Tomasz hojnie obdarował Zawiszę „kolaską gdańską krytą do drogi”119.

Życzeniem Anny Zamoyskiej było również, aby synowie udali się na Półwysep Iberyjski. Powodem dla odwiedzenia Hiszpanii miała być koronacja Filipa V, pierwszego Burbona na tronie tego kraju. Plany te nie zostały jednak zrealizowane $\mathrm{z}$ powodu opóźniającej się daty przybycia tego monarchy za Pireneje:

Co się tycze rozkazu WMM Pani i Dobrodziejki sławny peregrinatiej do Hiszpanijej na koronacyją króla hiszpańskiego, żeby to rzecz piękna była i chwalebna tylko, że tu dotychczas nie masz żadnej wiadomości o naznaczeniu jej czasu bo król młody jeszcze się zabawia we Francyjej ${ }^{120}$.

Prawdziwe powody niechęci braci do wyjazdu za Pireneje były chyba inne, gdyż Filip V przybył do Madrytu już w lutym t.r., koronując się wkrótce na króla Hiszpanii. Nie znajdujemy jednak w dostępnych źródłach żadnej wskazówki na ten temat.

W drodze powrotnej do kraju pierwotnie planowano udać się z Rzymu do Wenecji. Projekty te uległy jednak zmianie i w efekcie urządzono wycieczkę do Neapolu. Wyjazd nastąpił po 9 IV 1701 roku. Podróż, na tak krótkim odcinku trwająca prawie dwa tygodnie, wskazuje, że posuwano się niespiesznie, sycąc się urokami włoskich pejzaży urozmaiconych ruinami rzymskich budowli oraz widokami rolniczych krajobrazów, na które składały się gaje oliwne, figowe i pomarańczowe -

119 K. Zawisza, Pamiętniki Krzysztofa Zawiszy, wojewody mińskiego (1666-1721), opr. J. Bartoszewicz, Warszawa 1862, s. 97-98.

${ }^{120}$ AGAD, AZ 547, s. 107-108; Tomasz Zamoyski do matki, Rzym 27 I 1701. 
Przejechawszy tę tak miłą krainę z wielkim sercu ukontentowaniem, stanęliśmy w Neapolim, mieście dawnym na dwa tysiące lat przed narodzeniem Chrystusa Pana zmurowanym pod imieniem Parthenope. Miasto ledwie nie piękniejsze od Rzymu w samych jeno ustępujące pałacach, burk wszędzie równy jak w izbie i mała dyferencyja od ulic jak do wielkich galeryi ${ }^{121}$.

Największą atrakcją były dla nich uroczyste obchody święta św. Januarego, patrona miasta. Ze względu na nie pozostali w mieście do $1 \mathrm{~V}$. Każdy z braci opisał w swoich listach własne wrażenia:

A to jest takowa ceremonia. Naprzód wystawią w kaplicy krew świętego tego i krew zaraz niesą processionaliter na Wielki Ołtarz, które święte relikwie ex opposito postawione zaraz krew zaczyna wrzeć i ebulkire, skąd documenta populus bierze augurium co się stać ma tego roku ${ }^{122}$.

Tomasz Zamoyski okazał się znawcą koni rasowych i w związku z tym snuł również ambitne plany handlu szlachetnymi rumakami. Najstarszy z braci wysyłał do matki błagalne listy z prośbami o 3 tys. talarów na zakup koni, które - jak zapewniał - uda mu się z zyskiem sprzedać po powrocie do kraju: „choć i na burg będą kosztowały siła, ale w Polszcze nie straci się na nich”. Jednak Anna Zamoyska pozostała głucha na te prośby. Przebywając w Neapolu, Tomasz nie omieszkał podziwiać tamtejszych stadnin, skoro jeszcze wcześniej, z Rzymu, błagał matkę: „na konie neapolitańskie upraszamy bo piękne, dobre, pożyteczne i nie bardzo drogie, bo 500 szkutów najlepszy będzie" ${ }^{123}$. Ostatecznie z tych ambitnych projektów nic nie wyszło.

Zwiedzanie okolic Neapolu stanowiło nie lada atrakcję dla Zamoyskich. Tak jak i dla wielu innych turystów z Rzeczypospolitej, największym walorem tych terenów była możność poznania tradycji antycznych, ruin budowli i miejsc znanych z mitologii. Od XVII wieku zaznacza się także wzrost zainteresowania miejscową przyrodą i krajobrazem, a w szczególności ma-

${ }^{121}$ AGAD, AZ 549, s. 100-102; Marcin Zamoyski do matki, Neapol 23 IV 1701.

${ }_{122}$ AGAD, AZ 547, s. 133-135; Tomasz Zamoyski do matki, Neapol 23 IV 1701.

${ }^{123}$ Ibidem, s. 101, 115-116; Rzym 18 XII 1700, 26 II 1701. 
sywem wulkanu Wezuwiusz ${ }^{124}$. Braci Zamoyskich również należy zaliczyć w poczet wspinających się tam wczesnych polskich górołazów:

Widzieliśmy wiele raritates, jako to grotę Sybilli Kumeny nazwanej, drogę w skale wykowaną, wysoką, piękną. Starych Rzymian pogrzeby: Campos Elisyos, mare mortuum, przez które (według fabuł) przewozi Charon i stąd starzy kładli pieniądze w ręce umarłym. Vesuvius góra wiele nam dała fatygi bo wysoka, ale i ukontentowania bo ciekawym należyta do wiadomości, opisanie jej jest tak pospolite w książkach, że już z niej więcej nie jest miraculum ${ }^{125}$.

Po powrocie z Neapolu do Rzymu kontynuowano naukę, która jednak przez cały okres rzymski była zawężona głównie do studium historii. Zaniechano zupełnie ćwiczeń jazdy konnej i posługiwania się bronią, gdyż „kawalerskie exercycyje” nie przypadły do gustu matce podróżników. Najwięcej problemów sprawiała im nauka retoryki, „bo nie mając praktyki i słów nie wiedząc skąd brać polskich (których dla innych języków umienia zapominamy) autorów jeno czytamy, którzy by to formowali iudistitium"126. Wiosną 1701 roku do matki podróżników dotarła smutna wieść o śmierci Krukowieckiego, który zmarł po długiej chorobie ${ }^{127}$. Po opuszczeniu pozostajacych za granicą Zamoyskich i wcześniejszym powrocie do kraju Krukowiecki przebywał jeszcze jako rezydent w klasztorze w Krasnymstawie, gdzie też zmarł ${ }^{128}$. Powzięto wówczas zamiar udania się na północ Półwyspu Apenińskiego w celu zwiedzania innych włoskich miast, „co skończywszy jedziem do Pragi dla języka i dla ochrony czasu, tam będziemy rozkazów macierzyńskich czekać, możem lustrować ostatek niemieckich krajów" ${ }^{29}$. Powrót do kraju znacznie opóźniło długie oczekiwanie na przysłanie pieniędzy. Od wyjazdu z Rzymu, na przełomie maja i czerwca 1701 roku, plany obejmowały zwiedzanie Genui, Florencji,

${ }^{124}$ H. Barycz, Podróże polskie do Neapolu w wiekach XV-XVIII, Warszawa 1939, s. $39-40$.

125 AGAD, AZ 549, s. 104; Marcin Zamoyski do matki, Neapol 23 IV 1701.

126 Ibidem, s. 108-109; Rzym 14 V 1701.

127 AGAD, AZ 547, s. 137-138; Tomasz Zamoyski do matki, Rzym 14 V 1701.

128 A. P. Bieś, L. Grzebień, M. Inglot, op. cit., t. 1, s. 197.

129 AGAD, AZ 548, s. 74-77; Michał Zamoyski do matki; Rzym 21 V 1701. 
Turynu, Mediolanu, Padwy i Wenecji. Później podróżnicy skierowali się do Pragi. Był to ostatni etap podróży. Czas poświęcano głównie na naukę języka niemieckiego. W związku ze śmiercią Krukowieckiego matka peregrynantów, w końcu sierpnia 1701 roku, wysłała do Pragi innego jezuitę, kapelana dworskiego Jana Ignacego Delamarsa (De la Marsa) ${ }^{130}$.

Ciekawym aspektem pobytu w Pradze było spotkanie z Samuelem Proskim, stałym posłem w Wiedniu, spokrewnionym i współpracującym blisko z wujem peregrynantów, Janem Gnińskim. Proski, kawaler maltański, powracał do kraju z misji na Maltę i do Rzymu, skąd wiózł relikwie świętych dla kościoła jezuickiego w Poznaniu. Zlecono mu również ważną misję dyplomatyczną w Polsce ${ }^{131}$. Mogło tu chodzić o jego starania, poparte posiadanymi dokumentami zakonnymi i papieskimi, o uzyskanie ordynacji ostrogskiej przez zakon joannitów, powołujących się na „wolę fundatorów”, o czym Proski poinformował Zamoyskich ${ }^{132}$. Młodzi magnaci powrócili do Polski pod koniec 1701 roku, zatrzymując się na dłużej w Ołoboku u swojej ciotki Konstancji Gnińskiej, skąd wysłali życzenia świąteczne, zapowiadając swój rychły powrót do domu - „przy zbliżającej się i dawno pożądanej synowskiej szczęśliwości, powracający i zakańczający peregrynacyją naszą”"133. $\mathrm{Z}$ pewnością moment powrotu do rodzinnego Zamościa został uświetniony uroczystym powitaniem ordynatów kończących peregrynację, według zwyczaju profesorowie miejscowej akademii witali bowiem peregrynantów z kolejnych pokoleń Zamoyskich oracjami i panegirykami ${ }^{134}$.

Zachowane diariusze i korespondencja podróżna pozwalają nie tylko na odtworzenie trasy i chronologii peregrynacji braci Zamoyskich, lecz również ich odbioru różnych przejawów rzeczywistości w zwiedzanych krajach. Recepcja sztuki nie odbiega zasadniczo od dość przeciętnego poziomu prezentowanego przez ogół podróżników staropolskich tego czasu. Zadbano jednak o należytą promocję młodzieńczej peregrynacji, zamawiając po powrocie do kraju portrety młodych ordynatów ukazanych w strojach cudzo-

130 A. P. Bieś, L. Grzebień, M. Inglot, op. cit. , t. 1, s. 304.

131 A. Przyboś, Proski Samuel, PSB, 1984-1985, t. 28, s. 512-513.

132 AGAD, AZ 549, s. 115-117; Marcin Zamoyski do matki, Praga 10 X 1701.

133 AGAD, AZ 551, s. 8; Marcin Zamoyski do matki, Ołobok 20 XII 1701.

${ }^{134}$ J. K. Kochanowski, op. cit., s. 234. 
ziemskich (Tomasza i Michała sportretowanych przez Josepha Meyera) ${ }^{135}$. Wyraźnie nawiązano w ten sposób do połączenia rodowej tradycji ordynackiej z obyciem i uzyskaniem kontaktów zagranicznych przez magnatów zamojskich ukazanych w kostiumach XVIII-wiecznych Europejczyków.

Blisko czteroletnia „wielka podróż” Zamoyskich spełnia zasadnicze kryteria wyjazdów zagranicznych typu Grand Tour. Poznawano wówczas największe ośrodki miejskie Francji, Włoch, Niemiec, Austrii, Niderlandów i Anglii. W trakcie peregrynacji łączono ze sobą komponent edukacyjny z aspektem poznawczym, sprowadzającym się do nabywania wiedzy krajoznawczej oraz wyrobienia artystycznego i poczucia estetyki. Wysoka pozycja społeczna młodych ordynatów oraz znaczne nakłady pieniężne zapewniały należytą ostentację. Dzięki tym czynnikom możliwe były bliskie kontakty z przedstawicielami polskiej magnaterii i szlachty podróżującymi po Europie, młodymi Sobieskimi i ich matką, dyplomacją watykańską, bywanie u kardynałów oraz audiencje u papieży w Rzymie. Zachowane relacje z tej podróży pozwalają wydobyć jej ważne składniki naukowe, poznawcze oraz towarzyskie, w których wyrażała się aktywność intelektualna, kognitywna i komunikacyjna młodych ordynatów Zamoyskich.

135 K. Ajewski, Zbiory artystyczne i galeria muzealna Ordynacji Zamojskiej w Warszawie, Kozłówka 1997, s. 94, 125-126. 